\title{
Perspectives of the Development of 16S rDNA Probe Specific for Algicidal and/or Algal-lytic Gliding Bacteria
}

\author{
Toshimichi Maeda, ${ }^{*}$ Masatada Murakami, ${ }^{*}$ Shin-ya Ohsugi, ${ }^{*}$ \\ Manabu Furushita, ${ }^{*}$ Atsushi Mitsutani, ${ }^{*}$ and Tsuneo Shiba* \\ *Department of Food Chemistry, National Fisheries University, Yoshimi, Shimonoseki 759-6595, Japan \\ (Received December 11, 1997)
}

Sequence analyses of small subunit ribosomal RNA gene (16S rDNA) were performed on 16 strains of gliding marine bacteria isolated at the time of bloom of Skeletonema costatum in Ariake Sea. The strains were comprised of 8 strains which have capabilities to kill and lyse Skeletonema costatum, 5 strains with algicidal or algal-lytic activity and 3 strains without activity. The strains were divided into 4 clusters including 1, 2, 3, and 10 strains. Cluster A, C and D were close to Cytophaga latercula, Flexibacter maritimus and Cytophaga marinoflava, respectively. Cluster B was close to Flavobacterium aquatile. Neither algicidal nor algal-lytic activity was restricted to any of the clusters. The strains of cluster $\mathrm{B}$ contained flexirubin and did not require addition of $\mathrm{Na}^{+}$in growth peptone media.

Key words: algicidal bacteria, algal-lytic bacteria, 16S rDNA

Red tides have inflicted serious damages to the aquaculture in Japanese coastal seawaters. For example, at the time of the bloom of Skeletonema costatum, inorganic nutrients are consumed vigorously and become quickly extinct, and then the extinction results in a color fading of Porphyra in aquaculture. ${ }^{1)}$ This color fading is called "iroochi"' in Japanese.

As a possible tool for repressing or predicting the bloom of $S$. costatum and also the other algae, algicidal and/or algal-lytic bacteria have attracted much attention. The population of a certain species of algae is quickly diminished in coincidence with the increase of such algicidal and/or algal-lytic bacteria. ${ }^{2)}$ Such bacteria are inhibitory to a given range of algal species, and isolated at the bloom of the algae. The species of algal-lytic and/or algicidal bacteria isolated so far is distributed among a wide variety of taxonomic divisions. ${ }^{3-10)}$

Mitsutani has recently isolated some gliding bacteria which kill and/or lyse $S$. costatum from the Ariake Sea, with a double-layered agar plate medium containing the cells of $S$. costatum. ${ }^{1)}$ The algicidal bacteria digest cytoplasmic materials of the alga, while the algal protoplasts were produced by the algal-lytic bacteria. A limited number of phenotypic characteristics, examined hitherto, suggested that these bacteria were monophyletic. Hence, the bacteria seemed to be an available tool for predicting or repressing the bloom of $S$. costatum if a specific DNA probe is developed for the bacteria. Development of such a DNA probe is a prerequisite for quickly monitoring the bacteria in environments.

In this experiment, we determined the sequence of small subunit ribosomal RNA gene (16S rDNA) of these algicidal and/or algal-lytic bacteria, together with the gliding bacteria without algicidal or algal-lytic activity, for estimating the perspectives for developing a DNA probe in $16 \mathrm{~S}$ rDNA for algicidal and/or algal-lytic bacteria. Phylogenetic diversity of the bacteria is a crucial point for developing a specific DNA probe.

\section{Materials and Methods}

\section{Bacterial Strains}

Bacterial strains were isolated from the Ariake Sea, with a double-layered agar plate medium which contained Skeletonema costatum NIES-324 strain. ${ }^{1)}$ The algal strain was axenically cultured in a modified SWM-III medium $^{11,12)}$ at $15^{\circ} \mathrm{C}$ before addition to the agar medium. An intermittent illumination, $12 \mathrm{~L}: 12 \mathrm{D}$, was provided at $35 \mu \mathrm{Em}^{-2} \mathrm{~S}^{-1}$ with an incandescent lamp. Bacterial strains forming a plaque around colony were isolated, and purified with the modified SWM-III medium supplemented with $0.1 \%$ of casitone (Difco) and $0.05 \%$ of yeast extract (Difco) or PPES-II medium. ${ }^{13)}$

\section{Examination of Algal-lytic and Algicidal Activity}

Definition of algal-lytic and algicidal activity was referred to Mitsutani and Mitsutani et al. ${ }^{1,3)}$ Algicidal bacteria digest cytoplasmic materials of the alga, while algallytic bacteria produce algal protoplast. The activities of the isolated strains were ascertained in a liquid culture of $S$. costatum. Briefly, the bacterial strains grown in the above peptone media was collected at an exponential growth phase, washed and suspended in SWM-III. The suspensions were inoculated into the culture of $S$. costatum. The numbers of algal cells were determined under a phasecontrast microscopy. Decrease of the algal cells was defined as an indication of the activity.

\section{DNA Extraction}

The bacterial strains were grown in PPES-II liquid medium. The cells were centrifuged and washed in a sterilized artificial seawater. ${ }^{14)}$ DNA was extracted based on the method of Keller and Manak, ${ }^{15}$ ) or by boiling the cells in sterilized distilled water.

\section{PCR Amplification of $16 S$ rDNA}

PCR amplification of 16S rDNA was accomplished us- 
ing an automatic thermal cycler (model 480, Perkin-Elmer Co.), with 30 thermal cycles of $94^{\circ} \mathrm{C}$ for $60 \mathrm{~s}, 60^{\circ} \mathrm{C}$ for $45 \mathrm{~s}$ and $72^{\circ} \mathrm{C}$ for $90 \mathrm{~s}$. Hot start at $94^{\circ} \mathrm{C}$ for $180 \mathrm{~s}$, and an extension at $72^{\circ} \mathrm{C}$ for $300 \mathrm{~s}$ after the cycles was also performed. A $100 \mu l$ of the reaction mixture contained 0.1 to $1.0 \mu \mathrm{g}$ of template DNA, $20 \mathrm{nmol}$ each of dNTP, $100 \mathrm{pmol}$ each of PCR primer, 1.35 unit of recombinant Taq DNA polymerase (Takara Co. Ltd., Shiga, Japan), $10 \mu l$ of $10-$ fold concentrated PCR buffer prepared by the manufacturer. The primers used in this experiment were $27 \mathrm{~F}$ (5'-AGAGTTTGATCMTGGCTCAG-3') and 1492R (5'-TACGGYTACCTTGTTACGACTT-3') which were correspondent to the position 8 to 27 and 1513 to 1492 in the Escherichia coli $16 \mathrm{~S}$ rDNA number, ${ }^{16)}$ respectively. Molecular size of PCR amplicon was determined with an agarose electrophoresis including a molecular marker at a constant voltage of $100 \mathrm{~V}$.

\section{PCR Direct Sequencing and Phylogenetic Analysis of $16 S$} $r D N A$

The excess dNTP and the remaining primers in PCR products were removed by filtration through a cartridge filter Suprec-02 (Takara Co. Ltd.). The purified products were directly sequenced by using a Dye terminator cycle sequencing kit (Perkin-Elmer Co.), with universal primer 338R (5'-CTGCTGCCTCCCGTAGGAGT-3') corresponding to the position of 357 to 338 in the Escherichia coli $16 \mathrm{~S}$ rDNA number. ${ }^{16)} \mathrm{PCR}$ amplification with a combination of 27F and RVM517R (5'-CAGGAAACAGCTATGACCGTATTACCGCGGATGCTGGC-3 ${ }^{\prime}$ ) primers was also repeated before sequencing by using Dye primer cycle sequencing kit after the purification with Suprec-02.

The search for 16S rDNA sequences similar to those of the gliding bacteria was performed using Similar Rank in RDP (Ribosomal Database Project) database. ${ }^{17}$ The $16 \mathrm{~S}$ rDNA sequences were aligned using a software Clustal W (v. 1.6) ${ }^{18)}$ Kimura's two-parameter model ${ }^{19)}$ was applied to the calculations of evolutionary distance. A phylogenetic tree was constructed by the neighbor-joining method. ${ }^{20)}$ Bootstrap analyses of 1000 replicates were carried out using Clustal W.

\section{Accession Numbers of 165 rDNA Sequences}

The 16S rDNA sequences used for the phylogenetic analysis include the sequences of Capnocytophaga canimorsus (GenBank accession no. L14637), Cap. gingivalis (L14639), Cap. ochracea (U41350), Cytophaga hutchinsonii (M58768), Cy. latercula (M58769), Cy. marinoflava (M58770), Cy. uliginosa (M62799), Escherichia coli (X80725), Flavobacterium columnare (M58781), Fla. flevense (M58767), Fla. hydatis (M58764), Fla. johnsoniae (M59051), Fla. gondwanense (M92278), Fla. salegens (M92279), Flectobacillus glomeratus (M58775), Flexibacter maritimus (M64629), Gelidibacter algens (U62914), Myroides odoratus (M58777) and Psychroserpens burtonensis (U62913) in GenBank nucleotide sequence database, and $C y$. lytica (RDP short ID, Cy. lytica), Fla. aquatile (F. aquatile), Fla. saccharophilum (F. saccharo) and Fla. succinicans (F. succinic) in RDP database.

The nucleotide sequences determined in this study have been submitted to the DDBJ nucleotide sequence database under accession numbers from AB008031 to AB008046.

\section{Flexirubin Test}

Existence of flexirubin was examined with the cells of slope and liquid cultures according to the method described by Reichenbach et al. ${ }^{21)}$ Briefly, a $20 \% \mathrm{KOH}$ was poured onto the slope culture, and then observed. Color shift to red or orange indicated the presence of flexirubin. In case of liquid cultures, the bacterial cells were centrifuged and serially extracted with methanol and chloroform. A drop of $20 \% \mathrm{KOH}$ was added to the extracts. Spectra were examined before and after the addition of $\mathrm{KOH}$. Peak shift toward a longer wavelength was recognized as an indication of the presence of flexirubin.

\section{Other Test}

Gram staining was performed with a Hucker's modification. ${ }^{22)}$ Motility was examined with a hanging drop preparation under a phase microscope. Gliding motility was examined with a plate medium containing $0.8 \%$ agar in SWM-III medium. Capability of acid production from carbohydrate was examined using MOF medium. ${ }^{23)}$ Kovacs's oxidase test ${ }^{24)}$ was performed with a filter strip prepared by Nissui Co. Color change was checked after $30 \mathrm{~s}$. Catalase test was performed with $3 \% \mathrm{H}_{2} \mathrm{O}_{2}$ solution according to the recommendation of Taylor and Achanzar. ${ }^{25)}$ Briefly, bacterial cultures were streaked onto the strip of filter paper. The filter paper was immersed into $3 \% \mathrm{H}_{2} \mathrm{O}_{2}$ solution. Bubbles from the surface of the cells on filer paper indicated the presence of catalase in bacterial cells. Cation requirement for growth was examined with the method of Colwell and Wiebe. ${ }^{26)}$ Quinone was extracted from a freeze-dried cell with chloroform/methanol (3:1), and purified on a thin layer chromatography based on the method of Collins et al. ${ }^{27)}$ After extraction from the gel and filtration through a filter (Sunprep 4-FH, Millipore), chemical identification was performed with a high performance liquid chromatography using a reverse-phase column (Ultrasphere ODS, Beckman). Methanol/ isopropylalcohol was flowed at $1 \mathrm{~m} l / \mathrm{min}$ at room temperature. Quinones were monitored at $275 \mathrm{~nm}$.

\section{Results and Discussion}

Figure 1 shows a phylogenetic relationship between the species of Flavobacterium-Cytophaga group and the gliding bacteria isolated from the Ariake Sea. The alignment was inferred from the sequences of 410 to $420 \mathrm{bp}$-length fragments of 16S rDNA which were correspondent to the position of 28 to 433 in the $E$. coli number. ${ }^{16)}$ The phylogenetic alignment of the species of FlavobacteriumCytophaga group was slightly different from that obtained from full sequence of $16 \mathrm{~S}$ rDNA. ${ }^{28,29)}$ The marine bacteria, Cytophaga latercula and Cy. marinoflava, were closely related to each other in the alignment based on the full sequence, ${ }^{28,29)}$ while these were distant in this alignment. In our experiment, the distance between $C y$. latercula and Cy. marinoflava was comparable to the distance between Cy. latercula and Flavobacterium aquatile which has been described as a terrestrial bacterium. The discrepancy could be caused by the inclusion of only the most variable region and the exclusion of conservative one in this experiment. Although it is not clear the alignment of which experiment describes a real evolutionary relationship, we have not con- 


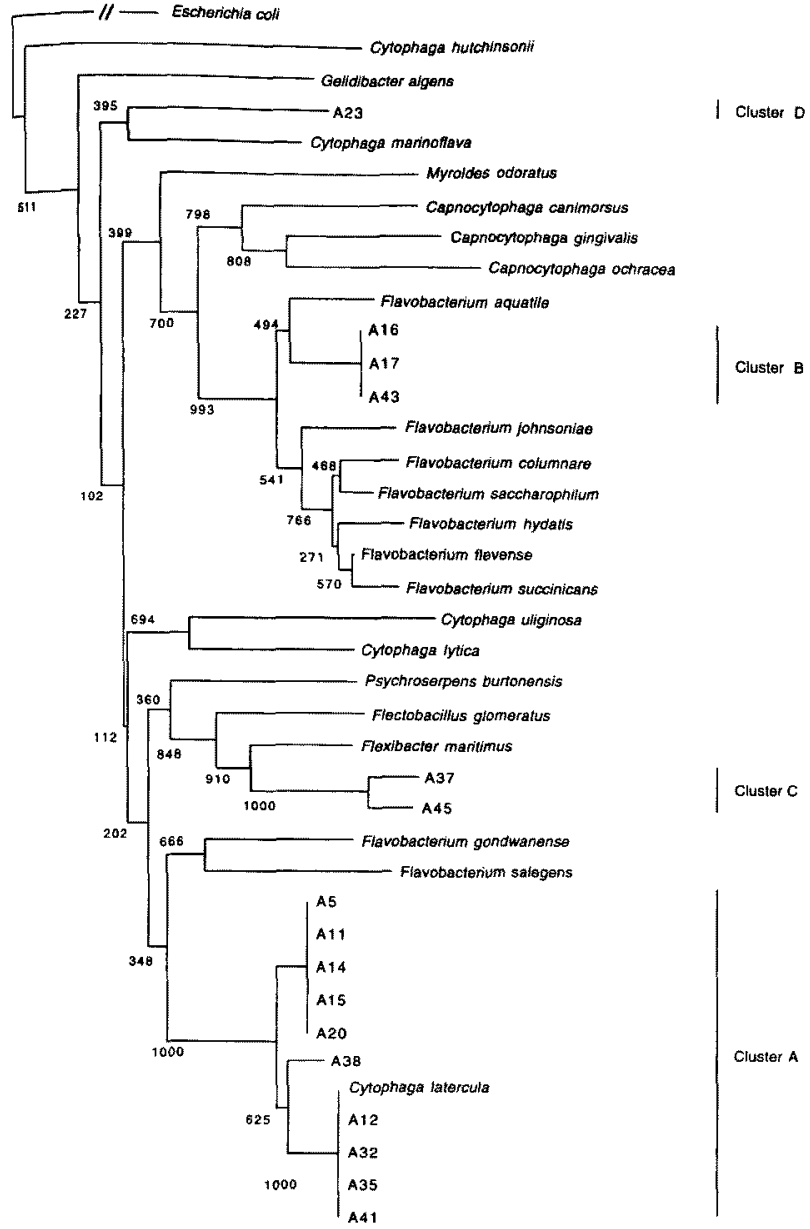

$0.1 k_{\text {nuc }}$

Fig. 1. Phylogenetic position of algicidal and/or algal-lytic bacteria within Flavobacterium-Cytophaga group, based on the partial $16 \mathrm{~S}$ rDNA sequences (the position from 28 to 443 in the $E$. coli $16 \mathrm{~S}$ IDNA).

ducted any further experiments, because the construction of a phylogenetic tree was not our purpose.

Total of 16 strains were divided into 4 clusters. Cluster A was comprised of strains A5, 11, 14, 15, 20, and strains A12, 32, 35, 41, and A38. The sequences of strains A5, 11, 14,15 and 20 were identical to each other and very similar to Cy. latercula. The strains A12, 32, 35 and 41 were also identical to each other. Strains A16, 17 and 43 formed cluster B, which was relatively close to Fla. aquatile. Strains A37 and 45 formed a third cluster, cluster C, which was a little distant from Flexibacter maritimus. Strain A23 (namely cluster D) may be grouped with $C y$. marinoflava. The clusters A, B and C included algicidal and/or algallytic bacteria, while cluster D did not.

Intercluster distances ( $K_{\text {nuc }}$ values) between clusters $A, B$ and $C$ ranged from 0.132 to 0.197 (Table 1). The distances among $C y$. latercula, Flex. maritimus and Fla. aquatile were estimated as from 0.132 to 0.175 in this experiment, while 0.065 to 0.092 in the full sequence analyses of $16 \mathrm{~S}$ iDNA. ${ }^{28)}$

Although the strains were distributed among different

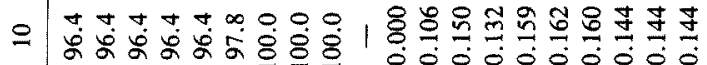

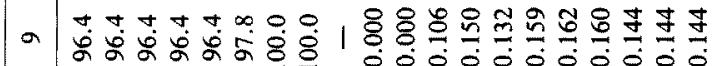

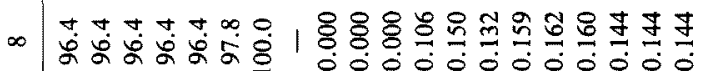

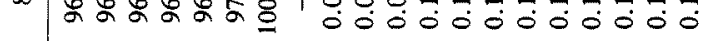

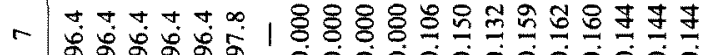

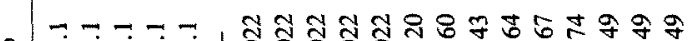
- मूล

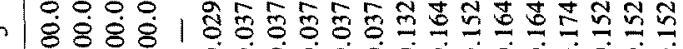
-

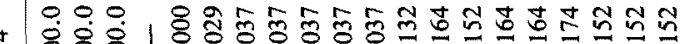

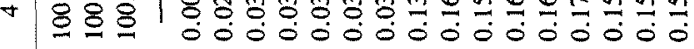

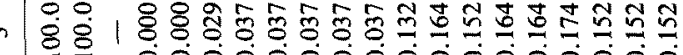
10000000000000000 N|官

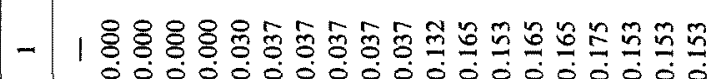

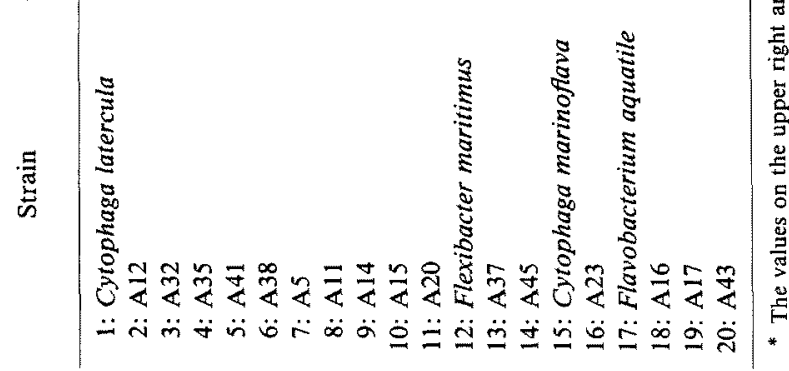


clusters, neither algicidal nor algal-lytic activity was restricted in any of the clusters, as in Table 2. Also A41 and A45, which were neither algicidal nor algal-lytic, were included in cluster A and C, respectively. Cluster A and C included algicidal and/or algal-lytic bacteria. There is no data whether the species of Cytophaga, Capnocytophaga, Flectobacillus, Flexibacter and Flavobacterium, which were located between 4 clusters, were algicidal or algallytic. Hence development of any specific probe for algicidal or algal-lytic activity is still difficult, even though evolutionary distances among the bacterial species were converged in the range of 0.065 to 0.092 , as suggested from the full sequences. Even these values are quite large and suggest difficulty.

Table 3 summarizes phenotypic characteristics of the gliding bacteria. All of the strains were gram-negative rod and did not show flagella-motility. Gliding motility was observed. Catalase and oxidase were present. Acids were

Table 2. Algicidal and algal-lytic activities of gliding bacteria

\begin{tabular}{lccc}
\hline Strain & Cluster & Algicidal activity & Algal-lytic activity \\
\hline A5 & A & - & + \\
A11 & A & + & + \\
A12 & A & + & + \\
A14 & A & + & + \\
A15 & A & + & - \\
A20 & A & + & + \\
A32 & A & + & + \\
A35 & A & + & + \\
A38 & A & + & + \\
A41 & A & - & - \\
A16 & B & + & - \\
A17 & B & + & + \\
A43 & B & + & - \\
A37 & C & + & - \\
A45 & C & - & - \\
A23 & D & - & - \\
\hline
\end{tabular}

produced aerobically from some carbohydrates. All characteristics mentioned above are found commonly in the bacteria in marine-type Cytophaga group. ${ }^{21,28,30)}$ The major quinone in the gliding bacteria examined was menaquinone 6 which has been detected in the strains of $C y$. latercula, Cy. marinoflava and Fla. aquatile, but not in Cy. hutchinsonii. ${ }^{28)} C y$. hutchinsonii contains menaquinone 7.

Depending on the phenotypic characteristics of bacteria, the four clusters seemed to be divided into two major groups. The strains of cluster B were different from the others in non-requirement of $\mathrm{Na}^{+}$for growth, despite that they were isolated from marine environment with a seawater medium. Also flexirubin was found in the strains of cluster B as a major pigment, but not in the other clusters. Flexirubin has not yet been reported to be present in Fla. aquatile. ${ }^{30)}$ Phenotypic and phylogenetic data in the experiment suggested that some of the gliding bacteria were not included in any of the known species. Description of these bacterial strains as a new species with further experiment should be valuable in bacterial taxonomy.

In this experiment, data indicated a wide distribution of algicidal and algal-lytic activities among FlavobacteriumCytophaga group. Mitsutani also has isolated algicidal bacteria included in the genus Alteromonas, ${ }^{1)}$ from the seawater sample collected at the station where the gliding bacteria in this experiment were isolated. Hence it should be difficult to investigate the ecological phenomena of algicidal and algal-lytic activities with a single DNA probe. Distinction between algal-killing and non-killing bacteria by using $16 \mathrm{~S}$ rDNA as a target gene is also impossible. Search for other genetic materials is necessary for developing a probe for algicidal and/or algal-lytic activities. Or, a search for a specific indicative strain, which has algicidal and/or algal-lytic activity and coordinates always with algal bloom would be valuable for developing a probe for algicidal and/or algal-lytic activities.

Table 3. General characteristics of gliding bacteria isolated at the time of bloom of Skeletonerna costatum

\begin{tabular}{|c|c|c|c|c|c|c|c|c|c|c|c|c|c|c|c|c|c|c|}
\hline \multicolumn{3}{|c|}{ Strain } & $\mathrm{A} 12$ & A 32 & A35 & A41 & A5 & Al1 & A 14 & A15 & $\mathrm{A} 20$ & A38 & A23 & A 37 & A45 & A16 & A17 & $\mathrm{A} 43$ \\
\hline \multicolumn{3}{|l|}{ Cluster } & A & A & A & A & A & A & A & A & A & A & D & C & C & B & B & B \\
\hline \multicolumn{3}{|l|}{ Gram } & - & - & - & - & - & - & - & - & - & - & - & - & - & - & - & - \\
\hline \multicolumn{3}{|l|}{ Catalase } & + & + & + & + & + & + & + & + & + & + & + & + & + & + & + & + \\
\hline \multicolumn{3}{|l|}{ Oxidase } & + & + & + & + & + & + & + & + & + & ND & ND & + & ND & + & + & + \\
\hline \multirow[t]{5}{*}{ OF test } & \multicolumn{2}{|c|}{ glucose } & $\mathrm{O}$ & 0 & 0 & ND & ND & - & - & - & - & 0 & ND & 0 & ND & 0 & 0 & $\mathbf{O}$ \\
\hline & \multicolumn{2}{|c|}{ galactose } & 0 & ND & ND & 0 & - & - & - & - & - & $\mathrm{O}$ & - & - & $\mathrm{O}$ & - & - & - \\
\hline & \multicolumn{2}{|c|}{ maltose } & $\mathrm{O}$ & ND & ND & 0 & 0 & $\mathrm{O}$ & 0 & 0 & $\mathrm{O}$ & 0 & 0 & 0 & 0 & 0 & 0 & O \\
\hline & \multicolumn{2}{|c|}{ cellobiose } & 0 & ND & ND & $\mathrm{O}$ & - & - & - & - & - & $\mathrm{O}$ & - & - & $\mathrm{O}$ & - & - & $\mathrm{O}$ \\
\hline & \multicolumn{2}{|c|}{ xylose } & 0 & ND & ND & $\mathrm{O}$ & - & - & - & - & - & 0 & - & - & $\mathrm{O}$ & - & - & - \\
\hline \multicolumn{3}{|c|}{ Motility } & glid & glid & glid & glid & glid & glid & glid & glid & glid & glid & glid & glid & glid & glid & glid & glid \\
\hline \multicolumn{3}{|c|}{ Cell form } & long & long & long & long & long & long & long & long & long & long & long & long & long & long & long & long \\
\hline \multirow{4}{*}{\multicolumn{2}{|c|}{ Requirement of }} & $\mathrm{K}^{+}$ & + & + & + & + & + & - & - & - & - & + & - & - & - & - & - & - \\
\hline & & $\mathrm{Na}^{+}$ & + & + & + & + & + & + & + & + & + & + & + & + & + & - & - & - \\
\hline & & $\mathrm{Mg}^{2+}$ & + & + & + & + & + & + & + & + & - & + & + & - & - & - & - & - \\
\hline & & $\mathrm{Ca}^{2+}$ & - & - & - & - & - & - & - & - & - & - & - & - & - & - & - & - \\
\hline \multirow[t]{5}{*}{ Growth at } & \multicolumn{2}{|c|}{$\mathrm{pH} 5$} & - & - & - & - & - & - & - & - & - & - & - & - & - & - & - & - \\
\hline & \multicolumn{2}{|c|}{ pH6 } & - & - & - & - & - & - & - & + & + & - & - & - & + & + & + & + \\
\hline & \multicolumn{2}{|c|}{$\mathrm{pH} 8$} & + & + & + & + & + & + & + & + & + & + & + & + & + & + & + & + \\
\hline & \multicolumn{2}{|c|}{ pH9 } & + & + & + & + & + & + & + & + & + & + & + & + & + & + & + & + \\
\hline & \multicolumn{2}{|c|}{$\mathrm{pH} 10$} & - & - & - & - & - & - & - & - & - & - & - & - & - & - & - & - \\
\hline \multicolumn{3}{|l|}{ Quinone } & MK6 & MK6 & MK6 & MK6 & MK6 & MK6 & MK6 & MK6 & MK6 & MK6 & MK6 & MK6 & MK6 & MK6 & MK6 & MK6 \\
\hline \multicolumn{3}{|l|}{ Flexirubin } & - & - & - & - & - & - & - & - & - & - & - & - & - & + & + & + \\
\hline
\end{tabular}

ND, not done; O, oxidative; glid, gliding motility; MK6, menaquinone 6 . 
Acknowledgments The author express sincere thanks to Eisai Co. for the gift of the standard chemicals for quinones. Also we are grateful to Dr. Ishida, of Fukuyama University, for encouragement. The work was supported by the grant-in-aid from the Agricultural, Forestry and Fishery Ministry of Japan.

\section{References}

1) A. Mitsutani: Ecological and physiological studies on algal lytic bacteria in lakes and coastal waters. J. Natl. Fish. Univ., 45, 165-257 (1997).

2) K. Fukami, T. Nishijima, H. Murata, S. Doi, and Y. Hata: Distribution of bacteria influential on the development and the decay of Gymnodinium nagasakiense red tide and their effects on algal growth. Nippon Suisan Gakkaishi, 57, 2321-2326 (1991).

3) A. Mitsutani, K. Takesue, M. Kirita, and Y. Ishida: Lysis of Skeletonema costatum by Cytophaga sp. isolated from the coastal water of the Ariake Sea. Nippon Suisan Gakkaishi, 58, 2159-2167 (1992).

4) I. Imai, Y. Ishida, S. Sawayama, and Y. Hata: Isolation of a marine gliding bacterium that kills Chattonella antiqua (Raphidophyceae). Nippon Suisan Gakkaishi, 57, 1409 (1991).

5) I. Imai, Y. Ishida, K. Sakaguchi, and Y. Hata: Algicidal marine bacteria isolated from northern Hiroshima Bay, Japan. Fisheries Sci., 61, 628-636 (1995).

6) Sukoso and T. Skata: Effect of co-existent bacteria on the growth of Chattonella marina in non-axenic culture. Fisheries Sci, 62, 210214 (1996).

7) S. Ishio, R. E. Mangindaan, M. Kuwahara, and H. Nakagawa: A bacterium hostile to fiagellates: identification of species and characters, in "Red Tides" (ed. by T. Okaichi, D. M. Anderson, and T. Nemoto), Elsevier, New York, 1989, pp. 205-208.

8) K. Fukami, A. Yuzawa, T. Nishijima, and Y. Hata: Isolation and properties of a bacterium inhibiting the growth of Gymnodinium nagasakiense. Nippon Suisan Gakkaishi, 58, 1073-1077 (1992).

9) T. Sakata and K. Iwamoto: Isolation of marine algicidal microorganisms on diatom double layer agar plaques. Fisheries. Sci., 61, 173-174 (1992).

10) I. Yoshinaga, T. Kawai, T. Takeuchi, and Y. Ishida: Distribution and fluctuation of bacteria inhibiting on the growth of a marine red tide phytoplankton Gymnodinium mikimotoi in Tanabe bay (Wakayama Pref., Japan). Fisheries Sci., 61, 780-786 (1996).

II) L. C. M. Chen, T. Edelstein, and J. Mclachlan: Bonnemaisonia hamifera Hariot in nature and in culture. J. Phycol., 5, 211-220 (1969).

12) K. Itoh and I. Imai: Rafido so (Raphidophyceae) in "A Guide for Studies of Red Tide Organisms" (ed. by Japan Fish. Resource Conservation Assoc.), Shuwa, Tokyo, 1987, pp. 122-130 (in Japanese).

13) N. Taga: Some ecological aspects of marine bacteria in the Kuroshio Current. Bull. Misaki Mar. Biol. Inst., 12, 56-76 (1968).

14) J. Lymann and R. H. Fleming: Composition of seawater. J. Mar.
Res., 3, 134-140 (1940).

15) G. H. Keller and M. M. Manak: DNA Probes, Stockton Press, New York, 1989, p. 43

16) J.-M. Neefs, Y. Van de Peer, L. Hendriks, and R. de Watcher: Compilation of small ribosomal subunit RNA sequences. Nucleic Acids Res., 18 Suppl, 2237-2317 (1990).

17) B. L. Maidak, G. J. Olsen, N. Larsen, R. Overbeek, M. J. McCaughey, and C. R. Woese: The RDP (Ribosomal Database Project). Nucleic Acids Res., 25, 109-111 (1997).

18) J. D. Thompson, D. G. Higgins, and T. J. Gibson: CLUSTAL W: improving the sensitivity of progressive multiple sequence alignment through sequence weighting, positions-specific gap penalties and weight matrix choice. Nucleic Acids Res., 22, 4673-4680 (1994).

19) M. Kimura: A simple method for estimating evolutionary rates of base substitutions through comparative studies of nucleotide sequences. J. Mol. Evol., 16, 111-120 (1980).

20) N. Saitou and $M$. Nei: The neighbor-joining method: a new method for reconstructing phylogenetic trees. Mol. Biol. Evol, 4, 406-425 (1987).

21) H. Reichenbach, W. Kohl, and H. Achenbach: The flexirubin-type pigments, chemosystematically useful compounds, in "The Flavobacterium-Cytophaga group", Verlag Chemie, Weinheim, Deerfield Beach, Florida, Basel, 1981, pp. 101-108.

22) Society of American Bacteriologists: Manual of Microbiological Methods, McGraw-Hill, New York, 1957, p. 16.

23) E. Leifson: Determination of carbohydrate metabolism of marine bacteria. J. Bacteriol., 85, 1183-1184 (1963).

24) N. Kovacs: Identification of Pseudomonas pyocyanea by the oxidase reaction. Nature, 178, 703, (1956).

25) W. I. Taylor and D. Achanzar: Catalase test as an aid in the identification of Enterobacteriaceae. Appl. Microbiol., 24, 58-61, (1972).

26) R. R. Colwell and W. J. Wiebe: "Core" characteristics for use in classifying aerobic, heterotrophic bacteria by numerical taxonomy. Bull. Ga. Acad. Sci., 28, 165-185 (1970).

27) M. D. Collins, H. N. Shah, A. S. McKee, and R. M. Kroppenstedt: Chemotaxonomy of the genus Capnocytophaga (Leadbetter, Holt, and Socransky). J. Appl. Bacteriol., 52, 409-415 (1982).

28) Y. Nakagawa and K. Yamasato: Phylogenetic diversity of the genus Cytophaga revealed by $16 \mathrm{~S}$ rRNA sequencing and menaquinone analysis. J. Gen. Microbiol., 139, 1155-1161 (1993).

29) Y. Nakagawa and K. Yamasato: Emendation of the genus Cytopha$g a$ and transfer of Cytophaga agarovorans and Cytophaga salmonicolor to Marinilabilia gen. nov.: phylogenetic analysis of the Flavobacterium-Cytophaga complex. Int. J. Syst. Bacteriol., 46, 599-603 (1996).

30) B. Holmes: The genera Flavobacterium, Sphingobacterium, and Weeksella, in "The Prokaryotes", 2nd. (ed. by A. Balows, H. G. Trüper, M. Dworkin, W. Harder, and K.-H. Schleifer), Springer Verlag, New York, 1991, pp. 3620-3630. 